\title{
AN OBSERVATIONAL STUDY TO ASSESS THE KNOWLEDGE OF STAFF NURSES REGARDING SEGREGATION OF NEEDLES AND SYRINGES IN CHILD HEALTH CARE AREAS OF CMC AND HOSPITAL, LUDHIANA, PUNJAB.
}

Davinder Kaur

\section{Prem Lata}

Prakash*

Neeta Austin Singha
Clinical Instructor, RN, BSN, MSN (Child Health Nursing) Christian Medical College \& Hospital Ludhiana, Punjab, India-141008.

Professor, RN, BSN, MSN (Child Health Nursing) Christian Medical College \& Hospital Ludhiana, Punjab, India-141008. *Corresponding Author

Associate Professor, RN, BSN, MSN (Psychiatric Nursing) Christian Medical College \& Hospital Ludhiana, Punjab, India-141008.

ABSTRACT) The study was conducted with the aim to assess the knowledge of segregation of needles and syringes among staff nurses in Child Health Care Areas of Christian Medical College (CMC) and Hospital, Ludhiana, Punjab. The objectives of the study were to assess the knowledge, find out the correlation between knowledge with selected variables and identify the deficit in areas of knowledge. Non-experimental research design and descriptive approach was used. Purposive sampling technique was used and sample size was 60. Self-Structured knowledge questionnaire was used to assess the knowledge. Data analysis was done using descriptive and inferential statistics. Findings revealed that majority of the staff nurses had average knowledge with maximum in the area of complications of inappropriate segregation and minimum regarding legal aspects. Selected variables such as age, work experience, professional qualification, in-service education, marital status and training institute had no impact on knowledge. Maximum knowledge deficit was regarding the authorities which make guidelines and decide penalty and least regarding primary source and color coding of biomedical waste. Lesson plan was devised to increase the knowledge of staff nurses.

\section{KEYWORDS : Knowledge, Segregation, Needles, Syringes, Staff nurses}

\section{INTRODUCTION}

Nurses are involved in waste generation, segregation, disinfection, and so forth. Healthcare service providers generally aim at controlling and preventing diseases such as communicable ones. However, in the course of activities, the generation of hazardous and nonhazardous waste is a concern of an environmental risk to healthcare workers, the public and the environment at large (M.Azage, A. Kumie, 2010) ${ }^{1}$.

Unsafe injection practices resulting from inappropriate segregation of needles and syringes can transmit Hepatitis B, Hepatitis C, Human Immunodeficiency Virus (HIV) and other blood borne pathogens have resulted in substantial burden of preventable blood borne viral diseases (BBVDs). The transmitted BBVDs remain silent for many years so the threat can be overlooked (Miller MA, Pisani E, 1999)'2.

Failure of appropriate segregation of needles and syringes and other healthcare waste turns nonhazardous waste into hazardous. Segregation also enables those who handle the containers outside the hospital wards to identify and treat them appropriately. (Patil AD, Shekdar AV, 2001) ${ }^{3}$.

The purpose of this study was to assess the existing level of knowledge regarding segregation of needles and syringes among staff nurses working in the child health care areas. It will provide baseline data for higher authorities to plan for an initiation for staff development in order to improve quality of care. This study will guide the health authorities in future planning of hospital waste management.

\section{Need Of The Study:}

Health care workers especially staff nurses are in close contact with patients, their blood and body fluids while administering injectable drugs. Most of the hospital acquired blood borne- infections are contacted through infected needle via needle pricks. WHO has already laid down emphasis on universal precautions for safety and also safe injection practices. For safe injection practices staff nurses need to have optimum knowledge regarding segregation of needles. It is therefore highly crucial to assess the current knowledge of staff nurses regarding the needle segregation techniques and practices. (Kotwal A, Taneja DK, 2010).

Potential infectious risks include the spread of infectious diseases and microbial resistance from healthcare establishments into the environment and thereby posing risks of getting infections and antibiotic resistance in the communities. However, the waste produced by the health care centres if disposed of improperly, can pose an even greater threat than the original diseases themselves due to the presence of concentrated forms of numerous risks including pathogenic and antibiotic resistant microorganisms (Sharma DR , Pradhan B, Mishra SK, 2010) ${ }^{5}$.

Other hazards associated with poor waste management includes injuries from sharps, risks associated with hazardous chemicals or drugs and disposables being repacked and sold without being washed. Waste piles also attract variety of disease vectors, including mosquitoes and flies (Acharya DB, Singh M, 2000).

So the investigator during clinical experiences felt that there is a need to conduct a study to assess the knowledge regarding segregation of needles in order to create awareness among staff nurses regarding appropriate segregation practices of needles and syringes.

\section{OBJECTIVES:}

1. To assess the level of knowledge of staff nurses regarding segregation of needles and syringes

2. To find out the relationship between knowledge regarding segregation of needles and syringes among staff nurses with selected variables such as age, professional qualification, marital status, Training Institute, work experience in child health care area and inservice education.

3. To find out the deficits in knowledge regarding segregation of needles and syringes in a view of conducting teaching as in-service education.

\section{Delimitations}

Sample size was limited to staff nurses in Child Health Care Areas of CMC and Hospital, Ludhiana.

\section{MATERIALAND METHODS}

Non-experimental research design and descriptive approach was used Target population comprised of 60 staff nurses working in child health care areas i.e. Paediatric Medical and surgical wards, Paediatric Intensive Care Unit (PICU), Neonatal Intensive care Unit (NICU) and Paediatric OPD.

Prior to the data collection, permission from Nursing Superintendent, approval from the research and ethical committee of College of Nursing, CMC \& Hospital, Ludhiana, and Punjab and a written informed consent from participating staff nurses was taken. Participants were assured that their anonymity and confidentiality would be maintained. Descriptive and inferential statistics such as mean, mean percentage, standard deviation, $\mathrm{z}$-test, t-test and ANOVA were used. The level of significance chosen was $\mathrm{p}<0.05$. 
Volume - 10 | Issue - 12 | December - 2020 | PRINT ISSN No. 2249 - 555X | DOI : 10.36106/ijar

\section{Description Of Tool}

Tool used in the study was divided into two parts:

Part-I: Demographic profile of staff nurses

This part of the tool was for obtaining personal information from staff nurses, i.e. age, professional qualification, marital status, work experience in child health care area, , in service education, and training institute.

Part -II: Self- Structured, pre- validated knowledge questionnaire consisting of 40 items for assessing the knowledge of staff nurses regarding segregation of needles and syringes was developed.

\section{Major Findings:}

Findings Related To Sample Characteristics As Depicted In Table 1:

- Majority i.e. $45 \%$ of the nurses were in the age group of 30-39 and least ( $5 \%)$ in the age group of 50 years and above.

- Majority of the nurses i.e $95 \%$ were females while only $5 \%$ were males.

- According to Professional qualification, majority of the nurses i.e. $73.3 \%$ were G.N.M while only $8.3 \%$ had done Post Basic Bsc (N).

- Majority of nurses were married (61.6\%) while none were divorced.

- Majority of nurses were trained from College of Nursing, CMC \& Hospital (61.6\%) while remaining $38.3 \%$ had been trained from other institutions.

- Majority $(28.3 \%)$ of nurses were working in Paediatric Medical ward only $6.6 \%$ from Paediatric OPD.

- Most of the nurses (35\%) had work experience of 1-5 years while $31.6 \%$ of $0-1$ year.

- Majority (53.3\%) of the nurses had received in service education in the form of orientation while only $10 \%$ had received skilled training.

\section{Findings Related To Knowledge:}

- Most nurses (51.6\%) had average knowledge followed by $33.3 \%$ with good knowledge and $13.3 \%$ having below average knowledge while only one $(1.66 \%)$ had excellent knowledge as depicted in Table 2(a).

- Mean \% score of knowledge was highest $(77 \%)$ regarding complications of inappropriate segregation followed by biomedical waste management $(61.9 \%)$, segregation of needles and syringes $(61.4 \%)$ and least i.e. (45\%) in legal aspects of violation of biomedical waste management as depicted in Table 2(b).

\section{Findings Related To Relationship Of Knowledge Of Staff Nurses} With Various Variables:

- Various variables studied had no impact on knowledge scores of staff nurses as depicted in Table 4(a,b,c,d,e,f,g \&h)

Findings Related To Deficit In Areas Of Knowledge:

Maximum deficit (90\%) in the knowledge was in item 2 and item 39 $(83.3 \%)$ pertaining to knowledge of the authorities making Biomedical waste management guidelines and deciding penalty for inappropriate segregation, while least staff nurses( $1 \%$ ) had deficits in knowledge regarding primary source of biomedical waste i.e. item no.3 and various colored bags used in biomedical waste management i.e. item no. $8(1.66 \%)$ as depicted in Table 5 .

Section I: Findings Related to Socio-demographic Characteristics of the sample

Table 1: Frequency And Percentage Distribution Of Sample Characteristics

$\mathbf{N}=\mathbf{6 0}$

\begin{tabular}{|l|l|l|}
\hline Sample Characteristics & f & \% \\
\hline 1. Age (in years ) & 25 & 41.6 \\
\hline a) $21-29$ & 27 & 45 \\
\hline b) $30-39$ & 5 & 8.3 \\
\hline c) $40-49$ & 3 & 5 \\
\hline d) More than 50 & \multicolumn{2}{l|}{} \\
\hline 2. Gender & 3 & 5 \\
\hline a) Male & 57 & 95 \\
\hline b) Female & \multicolumn{2}{|l|}{} \\
\hline 3. Professional qualification & 44 & 73.3 \\
\hline a) GNM & 11 & 18.3 \\
\hline b) B.Sc. (N) & 5 & 8.3 \\
\hline c) Post basic BSc(N)
\end{tabular}

\begin{tabular}{|l|l|l|}
\hline 4. Marital Status & 21 & 35 \\
\hline a) Unmarried & 37 & 61.6 \\
\hline b) Married & 2 & 3.33 \\
\hline c) Widow/Widower & 0 & 0 \\
\hline d) Separated & \multicolumn{2}{|l|}{} \\
\hline 5. Training Institute & 37 & 61.6 \\
\hline a) College Of Nursing (CON), CMC Ludhiana & 23 & 38.3 \\
\hline b) Other than CON, CMC Ludhiana & 17 & 28.3 \\
\hline 6. Present working area & 14 & 23.3 \\
\hline a) Paediatric medical ward & 16 & 26.6 \\
\hline b) NICU(Neonatal ICU) & 4 & 6.66 \\
\hline c) PICU (Paediatric ICU) & 9 & 15 \\
\hline d) Paediatric OPD & 19 & 31.6 \\
\hline e) Paediatric surgery ward & 21 & 35 \\
\hline 7. Work experience in Child Health Care area (years) \\
\hline a) 0-1 year & 20 & 33.3 \\
\hline b) 1-5 years & \multicolumn{2}{|l|}{} \\
\hline c) $>6$ years & 32 & 53.3 \\
\hline 8. In service education & 6 & 10 \\
\hline a) Orientation & 15 & 25 \\
\hline b) Skill training & 7 & 11.6 \\
\hline c) Continuing education &
\end{tabular}

Section II: Findings related to knowledge regarding segregation of needles and syringes among staff nurses

Objective 1: To assess the level of knowledge of staff nurses regarding segregation of needles and syringes.

Table 2 (a) : Frequency And Percentage Distribution Of Staff Nurses According To Levels Of Knowledge Regarding Segregation Of Needles And Syringes $\mathrm{N}=60$

\begin{tabular}{|l|l|l|l|}
\hline Levels of Knowledge & Score & F & $\%$ \\
\hline Excellent & $>32$ & 1 & 1.66 \\
\hline Good & $27-32$ & 20 & 33.3 \\
\hline Average & $21-26$ & 31 & 51.6 \\
\hline Below Average & $<20$ & 8 & 13.3 \\
\hline
\end{tabular}

Maximum score $=40$

Minimum score $=0$

Table 2(b): Mean, Standard Deviation, Mean Percentage And Rank Order Of Knowledge Score Of Staff Nurses Regarding Segregation Of Needles And Syringes According To Areas Of Knowledge $\mathbf{N}=\mathbf{6 0}$

Knowledge Score

\begin{tabular}{|l|l|l|l|l|l|}
\hline Knowledge Area & Max score & Mean & SD & Mean \% & Rank order \\
\hline
\end{tabular} Biomedical waste management

Segregation of needles and syringes

\begin{tabular}{l|l}
\hline Complications of & 4
\end{tabular} inappropriate segregation Legal aspects of violation of biomedical waste management

Maximum score $=40$

Minimum score $=0$

Section III: Findings related to relationship of knowledge of staff nurses with various variables.

\begin{tabular}{|l|l|l|l|l|}
\hline Knowledge Score \\
\hline Gender & n & Mean & SD & Z \\
\hline Male & 3 & 21 & 6.24 & \multirow{2}{*}{$0.28^{\text {NS }}$} \\
\hline & & & & \\
\hline Female & 57 & 24.8 & 3.78 & \\
\cline { 1 - 3 }
\end{tabular}

Objective 2: To find out the relationship between knowledge regarding segregation of needles and syringes among staff nurses with selected variables such as age, work experience in child health care area, professional qualification, in service education, marital status, training institute 
Volume - 10 | Issue - 12 | December - 2020 | PRINT ISSN No. 2249 - 555X | DOI : 10.36106/ijar

Table 4 (a): Mean, Standard Deviation And Analysis Of Variance Of Knowledge Score Of Staff Nurses Regarding Segregation Of Needles And Syringes According To Age (in Years) $\quad \mathrm{N}=60$

Knowledge Score

\begin{tabular}{|l|l|l|l|}
\hline Age(in Years) & n & Mean & SD \\
\hline $21-29$ & 25 & 24.9 & 3.96 \\
\hline $30-39$ & 27 & 24.7 & 3.88 \\
\hline $40-49$ & 5 & 26.8 & 5.97 \\
\hline$>50$ & 3 & 22.0 & 3.60 \\
\hline \hline
\end{tabular}

\begin{tabular}{|l|l|l|l|l|}
\hline \hline Source of Variation & df & $\begin{array}{l}\text { Sum of } \\
\text { Squares }\end{array}$ & $\begin{array}{l}\text { Mean Sum of } \\
\text { Squares }\end{array}$ & F \\
\hline Between Groups & 3 & 43.82 & 14.60 & \\
\hline Within Groups & 56 & 939.82 & 16.78 & $0.87^{\mathrm{NS}}$ \\
\hline Total & 59 & 983.65 & & \\
\hline
\end{tabular}

Maximum score $=40$

Minimum score $=0$

$\mathrm{NS}=$ Non-significant at $\mathrm{p}<0.05$ level

Table 4 (a): depicts the Mean, Standard Deviation and Analysis of Variance of Knowledge Score of Staff Nurses regarding Segregation of Needles and Syringes according to Age (in years). Mean knowledge score of staff nurses was highest in the age group of 40-49 (26.8), followed by the age group of 21-29 (24.9), (24.7) in age group 30 -39 and (22.0) in age group more than 50 years. The calculated ' $F$ ' value was 0.87 , which was less than the tabled value (2.76). The difference in mean was found to be statistically non significant at $\mathrm{p}<0.05$ level of significance.Hence, it can be concluded that age had no impact on knowledge of staff nurses regarding segregation of needles and syringes in Child Health Care Areas.

Table 4 (b) :mean, Standard Deviation And Z Test Of Knowledge Score Of Staff Nurses Regarding Segregation Of Syringes And Needles According To Gender $\mathbf{N}=60$

Maximum Score $=40$

Minimum score $=0$

$\mathrm{NS}=$ Non-significant at $\mathrm{p}<0.05$ leve

Table 4 (b): depicts the Mean, Standard Deviation and Z test of Knowledge Score of Staff Nurses regarding Segregation of Syringes and Needles according to Gender. Mean knowledge score was highest in female (24.8), followed by male staff nurses (21). The calculated Z value was 0.28 , which was less than the tabled value (2.00). The difference in mean was found to be statistically non significant at $\mathrm{p}<$ 0.05 level of significance. Hence, it can be concluded that gender had no impact on knowledge of staff nurses regarding segregation of needles and syringes in Child Health Care Areas.

Table 4 (c) : Mean, Standard Deviation And Analysis Of Variance Of Knowledge Score Of Staff Nurses Regarding Segregation Of Needles And Syringes According To Professional Qualification $\mathbf{N}=60$

Maximum score $=40$

Minimum score $=0$

$\mathrm{NS}=$ Non-significant at $\mathrm{p}<0.05$ level

Table 4 (c) : depicts Mean, Standard Deviation and Analysis of Variance of Knowledge Score of Staff Nurses regarding Segregation of Needles and Syringes according to Professional Qualification. The mean knowledge score of staff nurses was highest in staff nurses with Post Basic Nursing (27.4), followed by staff nurses with Basic B.Sc. nursing (26.6) and least (24.1) in staff nurses with GNM as professional qualification. The calculated ' $F^{\prime}$ value was 3.03 which was less than the tabled value (3.15). The difference in mean was found to be statistically non significant at $\mathrm{p}<0.05$ level of significance. Hence, it can be concluded that professional qualification had no impact on knowledge of staff nurses regarding segregation of needles and syringes in Child Health Care Areas.

Table 4 (d): Mean, Standard Deviation And Analysis Of Variance Of Knowledge Score Of Staff Nurses Regarding Segregation Of Needles And Syringes According To Marital Status N=60

Knowledge Score

\begin{tabular}{|l|l|l|l|}
\hline Marital Status & $\mathbf{n}$ & Mean & SD \\
\hline Unmarried & 21 & 25.57 & 3.2 \\
\hline Married & 37 & 24.43 & 4.4 \\
\hline
\end{tabular}

\begin{tabular}{|c|c|c|c|c|c|}
\hline Widow & \multicolumn{2}{|l|}{2} & \multirow{2}{*}{\begin{tabular}{|l|}
25.50 \\
24.43
\end{tabular}} & \multicolumn{2}{|l|}{3.5} \\
\hline Married & \multicolumn{2}{|l|}{37} & & \multicolumn{2}{|l|}{4.4} \\
\hline \multicolumn{2}{|c|}{ Source of Variation } & df & $\begin{array}{l}\text { Sum of } \\
\text { Squares }\end{array}$ & $\begin{array}{l}\text { Sum of } \\
\text { es }\end{array}$ & $\mathbf{F}$ \\
\hline \multicolumn{2}{|c|}{ Between Groups } & 2 & 18.20 & & \multirow{3}{*}{$0.55^{\mathrm{NS}}$} \\
\hline \multicolumn{2}{|c|}{ Within Groups } & 57 & 930.7 & 16.32 & \\
\hline \multicolumn{2}{|l|}{ Total } & 59 & 948.9 & & \\
\hline
\end{tabular}

Maximum score $=40$

Minimum score $=0$

$\mathrm{NS}=$ Non-significant at $\mathrm{p}<0.05$ level

Table 4 (d): depicts Mean, Standard Deviation and Analysis of Variance of Knowledge Score of Staff Nurses regarding Segregation of Needles and Syringes according to Marital Status. The mean knowledge score of staff nurses was highest in staff nurses who were unmarried (25.57), followed by widows (25.50), married (24.43) while none of the staff nurses had been separated. The calculated ' $F$ ' value was 0.55 which was less than the tabled value (3.15). The difference in mean was found to be statistically non significant at $\mathrm{p}<0.05$ level of significance. Hence, it can be concluded that marital status had no impact on knowledge of staff nurses regarding segregation of needles and syringes in Child Health Care Areas.

Table 4 (e): Mean, Standard Deviation And Z Test Of Knowledge Score Of Staff Nurses Regarding Segregation Of Needles And Syringes According To Training Institute $\mathrm{N}=\mathbf{6 0}$

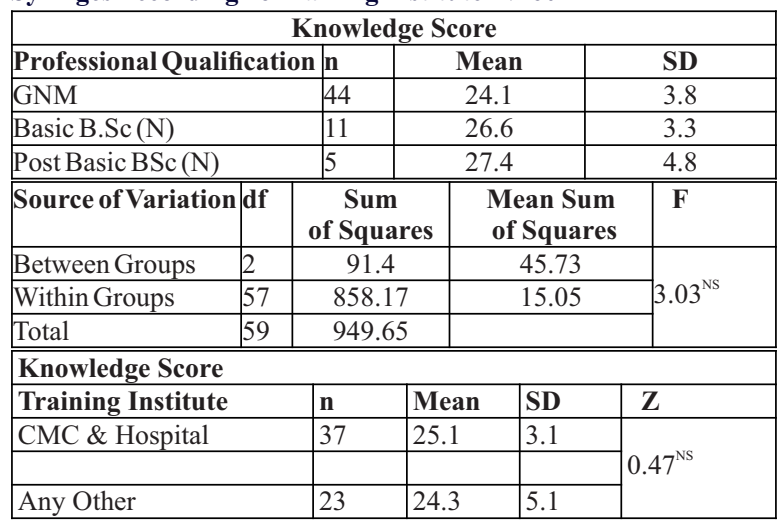

Maximum score $=40$

Minimum score $=0$

$\mathrm{NS}=$ Non significant at $\mathrm{p}<0.05$ level

Table 4 (e) : depicts Mean, Standard Deviation and Z test of Knowledge Score of Staff Nurses Regarding Segregation of Needles and Syringes according to Training Institute. The mean knowledge score was higher in the staff nurses who had been trained from College of Nursing, Christian Medical College (25.1), followed by staff nurses who had been trained from institution other than College of Nursing, Christian Medical College (24.3). The calculated $\mathrm{Z}$ value was 0.47 , which was less than the tabled value (2.00). The difference in mean was found to be statistically non significant at $p<0.05$ level of significance. Hence, it can be concluded that training institute had no impact on knowledge of staff nurses regarding segregation of needles and syringes in Child Health Care Areas.

Table 4 (f): Mean, Standard Deviation And Analysis Of Variance Of Knowledge Score Of Staff Nurses Regarding Segregation Of Needles And Syringes According To Working Area $\mathbf{N}=60$

\begin{tabular}{|c|c|c|c|c|c|}
\hline \multicolumn{6}{|l|}{ Knowledge Score } \\
\hline \multicolumn{3}{|l|}{ Working Area } & $\mathbf{n}$ & Mean & SD \\
\hline \multicolumn{3}{|c|}{ Pediatric Medical Ward } & 17 & 25.7 & 3.2 \\
\hline \multicolumn{3}{|c|}{ Neonatal Intensive care unit (NICU) } & 14 & 24.7 & 3.7 \\
\hline \multicolumn{3}{|c|}{ Pediatric Intensive care unit (PICU) } & 16 & 26.1 & 4.5 \\
\hline \multicolumn{3}{|c|}{ Pediatric OPD } & 4 & 21.0 & 2.4 \\
\hline \multicolumn{3}{|c|}{ Pediatric Surgery OPD } & 9 & 23.0 & 2.7 \\
\hline Source of Variation & df & \multicolumn{2}{|c|}{$\begin{array}{l}\text { Sum of } \\
\text { Squares }\end{array}$} & $\begin{array}{l}\text { Mean Sum of } \\
\text { Squares }\end{array}$ & $\mathbf{F}$ \\
\hline Between Groups & 4 & \multicolumn{2}{|l|}{131.07} & 32.76 & \multirow{3}{*}{$2.42^{\mathrm{NS}}$} \\
\hline Within Groups & 55 & \multicolumn{2}{|l|}{744.32} & 13.53 & \\
\hline Total & 59 & \multicolumn{2}{|l|}{875.4} & & \\
\hline
\end{tabular}


Minimum score $=0$

$\mathrm{NS}=$ Non-significant at $\mathrm{p}<0.05$ level

Table 4 (f): depicts Mean, Standard Deviation and Analysis of Variance of Knowledge Score of Staff Nurses regarding Segregation of Needles and Syringes according to Working Area. The mean knowledge score of staff nurses was highest in staff nurses who were working in Paediatric Intensive care unit (26.1), followed by staff nurses who were working in Paediatric Medical ward (25.7), staff nurses working in Neonatal Intensive care unit (24.7), staff nurses working in Paediatric surgery ward (23.0) and least in staff nurses working in Paediatric OPD (21.0) . The calculated ' $\mathrm{F}$ ' value was 2.42 which was less than the tabled value (2.52). The difference in mean was found to be statistically non significant at $\mathrm{p}<0.05$ level of significance.

Hence, it can be concluded that working area had no impact on knowledge of staff nurses regarding segregation of needles and syringes in Child Health Care Areas.

Table 4 (g): Mean, Standard Deviation And Analysis Of Variance Of Knowledge Score Of Staff Nurses Regarding Segregation Of Needles And Syringes According To Work Experience (in Years) $\mathrm{N}=60$

Knowledge Score

\begin{tabular}{|c|c|c|c|c|c|}
\hline \multicolumn{2}{|c|}{ Work experience (years) } & n & \multicolumn{2}{|l|}{ Mean } & SD \\
\hline \multicolumn{2}{|c|}{$0-1$} & 19 & \multicolumn{2}{|l|}{24.3} & 4.06 \\
\hline \multicolumn{2}{|l|}{$1-5$} & 21 & 25.2 & \multicolumn{2}{|l|}{4.3} \\
\hline \multicolumn{2}{|l|}{$>5$} & 20 & 25.0 & \multicolumn{2}{|l|}{3.6} \\
\hline Source of Variation & dff & & $\begin{array}{l}\text { Sum of } \\
\text { Squares }\end{array}$ & $\begin{array}{l}\text { Mean Sum } \\
\text { of Squares }\end{array}$ & $\mathbf{F}$ \\
\hline Between Groups & 2 & & 9.01 & 4.50 & \\
\hline Within Groups & 57 & & 939.91 & 16.48 & $0.27^{\mathrm{NS}}$ \\
\hline Total & 59 & & 948.93 & & \\
\hline
\end{tabular}

Maximum score $=40$

Minimum score $=0$

$\mathrm{NS}=$ Non-significant at $\mathrm{p}<0.05$ level

Table 4 (g) : depicts Mean, Standard Deviation and Analysis of Variance of Knowledge Score of Staff Nurses regarding Segregation of Needles and Syringes according to Work Experience (in years). The mean knowledge score of staff nurses was highest in staff nurses with work experience of 1-5 years (25.2), followed by staff nurses with work experience of more than 5 years (25.0) and least (24.3) in staff nurses with work experience $0-1$ year. The calculated ' $F$ ' value was 0.27 which was less than the tabled value (3.15). The difference in mean was found to be statistically non significant at $\mathrm{p}<0.05$ level of significance.

Hence, it can be concluded that work experience (in years) had no impact on knowledge of staff nurses regarding segregation of needles and syringes in Child Health Care Areas.

Table 4 (h): Mean, Standard Deviation And Analysis Of Variance Of Knowledge Score Of Staff Nurses Regarding Segregation Of Needles And Syringes According To In-service Education $\mathbf{N}=60$

\begin{tabular}{|l|l|l|l|l|}
\hline Knowledge Score & \multicolumn{5}{l|}{} \\
\hline In-service education & n & Mean & SD & \\
\hline Orientation & 32 & 24.37 & 4.4 & \\
\hline Skilled training & 6 & 24.33 & 2.8 & \\
\hline Continuing education & 15 & 26.40 & 3.8 & \\
\hline None & 7 & 24.28 & 2.4 & \\
\hline \hline Source of Variation & df & $\begin{array}{l}\text { Sum of } \\
\text { Squares }\end{array}$ & \multicolumn{1}{l|}{$\begin{array}{l}\text { Mean Sum Squares } \\
\text { of Squar }\end{array}$} & F \\
\hline Between Groups & 3 & 47.07 & 15.6 & \\
\hline Within Groups & 56 & 901.86 & 16.32 & $0.97^{\text {NS }}$ \\
\hline Total & 59 & 948.93 & & \\
\hline
\end{tabular}

Maximum score $=40$

Minimum score $=0$

$\mathrm{NS}=$ Non-significant at $\mathrm{p}<0.05$ level

Table 4 (h): depicts Mean, Standard Deviation and Analysis of variance of Knowledge Score of Staff Nurses regarding Segregation of Needles and Syringes according to In-service education. The mean knowledge score of staff nurses was highest in staff nurses who had inservice education as continuing education (26.40), followed by staff nurses who had in-service education as orientation (24.37), staff nurses who received in-service education as skilled training (24.33) while least in staff nurses who had not received in-service education (24.28). The calculated ' $F$ ' value was 0.97 which was less than the tabled value (2.76). The difference in mean was found to be statistically non significant at $\mathrm{p}<0.05$ level of significance

Hence, it can be concluded that in-service education had no impact on knowledge of staff nurses regarding segregation of needles and syringes in Child Health Care Areas.

Section III: Findings related to deficit in areas of knowledge

Objective 3: To find out the deficits in knowledge regarding segregation of needles and syringes in a view of conducting teaching as in-service education.

Table 5: Percentage Of Staff Nurses According To Deficits In Knowledge Regarding Segregation Of Needles And Syringes N=60

\begin{tabular}{|c|c|c|c|c|}
\hline & Knowledge items & $\mathbf{f}$ & $\%$ & Rank order \\
\hline \multicolumn{5}{|c|}{ A. BIOMEDICAL WASTE MANAGEMENT } \\
\hline 1) & The Biomedical waste includes: & 3 & 5 & 27 \\
\hline 2) & Guidelines for handling of Biomedical Waste (Management and Handling) Rule, 1998 laid down by: & 54 & 90 & 1 \\
\hline 3) & The primary source of biomedical wastes is: & 1 & 1.66 & 28 \\
\hline 4) & The CDC ( Centres For Disease Control And Prevention) after a needle stick injury recommends to: & 21 & 35 & 15 \\
\hline 5) & The guidelines for biomedical waste management have been revised recently in: & 16 & 26.6 & 19 \\
\hline 6) & The biomedical waste generated in child care areas includes: & 22 & 36.6 & 14 \\
\hline 7) & The time limit within which biomedical waste should be treated is: & 46 & 26.6 & 19 \\
\hline 8) & The different colors of bags used in biomedical waste management are: & 1 & 1.66 & 28 \\
\hline 9) & The bio - medical waste rules are applicable to: & 7 & 11.66 & 24 \\
\hline 10) & The colored bag and item collected in it is correctly matched EXCEPT: & 43 & 71.8 & 6 \\
\hline 11) & Biomedical waste includes all EXCEPT: & 14 & 23.3 & 21 \\
\hline 12) & Biomedical waste segregated in categories as per: & 46 & 76.6 & 4 \\
\hline \multicolumn{5}{|c|}{ B. SEGREGATION OF NEEDLES AND SYRINGES } \\
\hline 13) & The need for segregation of needles and syringes before disposal is to: & 19 & 31.6 & 16 \\
\hline 14) & The parts of a needle include all EXCEPT : & 34 & 56.5 & 10 \\
\hline 15) & Person responsible for segregation of needles and syringes is/are: & 3 & 5 & 27 \\
\hline 16) & Used syringes with fixed needles as per Schedule I are discarded in: & 15 & 25 & 20 \\
\hline 17) & The advantages of segregation are as follows: & 33 & 55 & 11 \\
\hline 18) & The following is true regarding segregation of needles and syringes EXCEPT: & 44 & 73.3 & 5 \\
\hline 19) & Needle cutter is used to: & 38 & 63.3 & 8 \\
\hline 20) & The sharp container should be emptied: & 48 & 80 & 3 \\
\hline 21) & Post segregation treatment options for needles is as follows EXCEPT: & 42 & 70 & 7 \\
\hline 22) & The segregated needles should be discarded in : & 9 & 15 & 23 \\
\hline 23) & Correct method of discarding a used needle is to: & 5 & 8.3 & 25 \\
\hline
\end{tabular}


Volume - 10 | Issue - 12 | December - 2020 | PRINT ISSN No. 2249 - 555X | DOI : 10.36106/ijar

\begin{tabular}{|c|c|c|c|c|}
\hline 24) & Pre-requisites for segregation include EXCEPT: & 18 & 30 & 17 \\
\hline 25$)$ & Ideally needles \& syringes should be segregated: & 7 & 11.66 & 24 \\
\hline 26) & Following is done during segregation EXCEPT: & 21 & 35 & 15 \\
\hline 27) & Segregation of biomedical waste is defined as: & 17 & 28.3 & 18 \\
\hline 28$)$ & Used needles can be disinfected with: & 4 & 6.6 & 26 \\
\hline 29) & The process of shredding involves: & 34 & 56.6 & 9 \\
\hline 30$)$ & Needles and syringes should be segregated as per Schedule I : & 26 & 43.3 & 13 \\
\hline 31) & Following is correct for needle cutter EXCEPT: & 26 & 43.3 & 13 \\
\hline 32$)$ & The ideal way to prevent syringe re-use is to: & 28 & 46.6 & 12 \\
\hline 33) & The segregated syringes (without needles) are disposed in: & 11 & 18.3 & 22 \\
\hline \multicolumn{5}{|c|}{ C. COMPLICATIONS OF INAPPROPRIATE SEGREGATION } \\
\hline 34) & The inappropriate segregation of needles and syringes is hazardous to: & 16 & 26.6 & 19 \\
\hline 35$)$ & Due to the inappropriate segregation of needles and syringes the diseases can be transmitted through: & 5 & 8.3 & 25 \\
\hline 36) & Environmental complications of inappropriate segregation of needles and syringes include: & 15 & 25 & 20 \\
\hline 37$)$ & Health hazard to the general public due to inappropriate segregation of needles and syringes include: & 19 & 31.6 & 16 \\
\hline \multicolumn{5}{|c|}{ D. LEGAL ASPECTS OF VIOLATION OF BIOMEDICALWASTE MANAGEMENT } \\
\hline 38$)$ & The penalty for inappropriate segregation of needles and syringes is decided by: & 15 & 25 & 20 \\
\hline 39) & Inappropriate segregation of biomedical waste for first time can lead to imprisonment for: & 50 & 83.3 & 2 \\
\hline 40$)$ & Inappropriate segregation of biomedical waste for first time can lead to a fine of: & 34 & 56.6 & 9 \\
\hline
\end{tabular}

Maximum score $=40$

Minimum score $=0$

Table 5: depicts the percentage of Staff Nurses According to Deficits in Knowledge Regarding Segregation of Needles and Syringes. This table describes the individual items in areas of knowledge where $90 \%$ (rank 1) of the staff nurses had deficits in knowledge regarding item no. $2.83 .3 \%$ (rank 2) staff nurses gave wrong answers for item no. 39 . $80 \%$ (rank 3 ) of the staff nurses gave incorrect answers for the item 20 . $76.6 \%$ (rank 4 ) of the staff nurses gave incorrect answer for item no. 12 . About $73.3 \%$ (rank 5) of the staff nurses did not know the correct answer to item no.18. The staff nurses that answered item no. 10 incorrectly were $71.8 \%$ (rank 6). $70 \%$ (rank 7) of the staff nurses answered item no. 21 incorrectly. The staff nurses that answered item no. 19 incorrectly were $63.3 \%$ (rank 8 ). $56.6 \%$ (rank 9) of the staff nurses did not know the correct answer to item no. 29 and item no. 40. Similarly $56.5 \%$ (rank 10) of the staff nurses did not know the correct answer to the item no. 14. 55\% (rank 11) of the staff nurses did not know the correct answer to item no.17. 46.6\% (rank 12) of the staff nurses did not know the correct answer to the item no. 32 while $43.3 \%$ (rank 13) of the staff nurses did not know the correct answer to the item no. $30,31.36 .6 \%$ (rank 14) staff nurses did know the correct answer to item no. $6.35 \%$ (rank 15) of the staff nurses did not answer item no. 26 and item no. 4 correctly and $31.6 \%$ (rank 16) of the staff nurses did not know the answer to the item no.13 and item no. $37.30 \%$ (rank 17) of the staff nurses failed to answer item no. 24 correctly and $28.3 \%$ (rank 18 ) of them were unable to answer item no. 27 correctly. $26.6 \%$ (rank 19) of the staff nurses could not answer the item no. 5, 7 and 34 correctly while $25 \%$ (rank 20 ) of them were unable to answer item no. 16,36 and 38 correctly. $23.3 \%$ (rank 21 ) of staff nurses were unable to answer correctly item no. 11 and $18.3 \%$ (rank 22) were unable to answer item no. 33 correctly.15\% (rank 23) of the staff nurses had knowledge deficit in item no.22. While $11.6 \%$ (rank 24) had deficit in item no. 25 and item no. $9.8 .3 \%$ (rank 25)of staff nurses had knowledge deficit in item no. 35 and 23 while $6.6 \%$ (rank 26) had deficits in answering item no. $28.5 \%$ (rank 27) of staff nurses had knowledge deficit in answering item no. 1 and 15 while 1.66\% (rank 28) of them were unable to answer item no. 3 and 8 correctly.

Hence, it can be concluded that maximum deficit of knowledge of staff nurses on segregation of needles and syringes was on item 2 i.e regarding the authority who makes guidelines for Biomedical waste management followed by item no. 39 which is regarding knowledge of authority which decides the penalty for inappropriate segregation of needles and syringes while least deficit in knowledge was for item no. 3 $\& 8$ i.e. regarding knowledge of primary source of biomedical waste and the different color coded bags used in biomedical waste management.

Objective- 3: To find out the deficits in the areas of knowledge regarding segregation of needles and syringes with a view of conducting teaching as in-service education.

\section{Validity Of The Lesson Plan}

On the basis of the findings of the study the lesson plan was prepared and distributed among various experts from the Area of Child Health Nursing, Community Health Nursing, Medical \& Surgical Nursing, Mental Health (Psychiatric) Nursing and Obstetric \& Gynecological
Nursing for the validity. Changes were made in the Lesson plan after the correction and valuable suggestions given by the experts. The final protocol was prepared and given to the staff nurses.

\section{DISCUSSION}

Based upon findings from analysis of data and review of literature, discussion of present study was done in accordance with the objectives of research problem. The findings of the study are discussed with reference to the results observed by other investigators The present study has been conducted to assess the knowledge of staff nurses regarding segregation of needles and syringes in child health care areas of CMC and Hospital, Ludhiana, Punjab.

Present study also assessed the relationship of knowledge of staff nurses with selected variables and to identify the deficits in areas of knowledge regarding the same. Knowledge questionnaire was prepared to assess the knowledge of 60 staff nurses regarding Segregation of needles and syringes.

Findings of the present study revealed that majority of the staff nurses $31(51.6 \%)$ had average knowledge regarding segregation of needles and syringes. These findings are supported by another study done by Indupalli and colleagues where majority had average knowledge regarding $92 \%$ color coding, $77 \%$ sources of bio-medical waste, $75 \%$ steps in segregation of needles and syringes and $68 \%$ diseases transmitted through it (Indupalli AS, Motakpalli K, Giri PA, Bendigiri NA, 2015) ${ }^{7}$. In another study majority of the healthcare workers had average knowledge regarding segregation of needles and syringes showing $58 \%$ of them with average knowledge regarding segregation of needles and syringes (Elnour AM, Reda Moussa MM, El-Borgy MD, Eltahir Fadelella NE, Mahmoud AH, 2015) ${ }^{8}$.

Findings of the present study depicts that the area wise mean percentage knowledge score was highest in the area of knowledge regarding complications of inappropriate segregation of needles and syringes 3.08 (77\%). followed by biomedical waste management 7.43 $(61.9 \%)$, segregation of needles and syringes $12.9(61.4 \%)$ and least i.e. $1.35(45 \%)$ in the area of knowledge regarding legal aspects of violation of biomedical waste management. These findings are in accordance with Bansal and group (Bansal M, Mishra A, Gautam P, Changulani R, Srivastava D, Gour NS, 2011) ${ }^{9}$ which was done to assess the knowledge and practices of healthcare workers regarding segregation of needles and syringes. In this study it was revealed that almost all i.e $116(100 \%)$ the health care workers were having knowledge about complications of inappropriate segregation of needles and syringes and 83 (71.55) had knowledge regarding segregation of needles and syringes.

In the present study, the structured questionnaire was used to assess the knowledge of staff nurses regarding segregation of syringes and needles. Another study by Yamini and group done to assess the knowledge, attitude and practices of healthcare workers regarding segregation of needles and syringes also used questionnaire (Yamini, Jain A, Mandelia C, Jayaram S, 2012) ${ }^{10}$.

In our study the socio-demographic characteristics had no impact on 
knowledge regarding segregation $\mathrm{f}$ needles and syringes. This is in contrast to what was seen in a study which showed years of experience, sex and level of education was statistically associated with the current knowledge and practice about injection safety among nurses. Now this contrast can be due to comparable work experience among the staff nurses included in our study (Birhanu D, Amare E, Belay A, Belay Y, $2019)^{11}$

\section{CONCLUSION}

On the basis of research findings it can be concluded that most of the staff nurses working in various child health care areas of Christian Medical College and Hospital had average knowledge regarding segregation of needles \& syringes. Socio-demographic characteristics had no impact on knowledge scores. According to the various areas staff nurses exhibited maximum knowledge in concepts related to complications of inappropriate segregation of biomedical waste and least in the legal aspects of violation of biomedical waste management. However the overall score of the subjects was unsatisfactory indicating the need for guidelines on segregation of needles \& syringes.

\section{Acknowledgements}

Authors are thankful to the management of CMC College of Nursing, Ludhiana for providing necessary research facility to carry out this research project.

\section{REFERENCES}

1. M. Azage, A. Kumie, "Healthcare waste generation and its management system: the case of health centers in West Gojjam Zone, Amhara Region, Ethiopia," Ethiop J Health Dev. 2010;24: 119-126.

2. Miller MA, Pisani E. The cost of unsafe injection. Bull World Health Organ. 1999; 77:808-11.

3. Patil AD, Shekdar AV, "Health-care waste management in India," J Environ Manage. 2001; 63:211-220.

4. Kotwal A, Taneja DK. Health Care Workers and Universal Precautions: Perceptions and Determinants of Non-compliance. Indian J Community Med. 2010; 35: 526-8

5. Sharma DR, Pradhan B, Mishra SK. Multiple drug resistance in bacterial isolates from liquid wastes generated in central hospitals of Nepal. Kathmandu Univ Med J.2010; 8: 40-44.

6. Acharya DB \& Singh M. The Book of Hospital waste Management. Minerva Press, New Delhi; 2000:p.5-47.

7. Indupalli AS, Motakpalli K, Giri PA, Bendigiri NA. Knowledge, Attitude \& Practices regarding Biomedical Waste Management amongst Nursing Staff of Khaja Banda regarding Biomedical Waste Management amongst Nursing Staff of Khaja Banda
Nawaz Institute of Medical Sciences, Kalburgi, Karnataka. Ntl J of Community Med Nawaz Institute of
2015; 6:562-565.

8. Elnour AM, Reda Moussa MM, El-Borgy MD, Eltahir Fadelella NE, Mahmoud AH. Impacts of health education on knowledge and practice of hospital staff with regard to healthcare waste management at White Nile state main hospitals, Sudan. Int J Health Sci. 2015; 9:315-331.

9. Bansal M, Mishra A, Gautam P, Changulani R, Srivastava D, Gour NS. Biomedical waste management: awareness and practices in a district of Madhya Pradesh. Nat J Comm Med.2011;2:452-456.

10. Yamini, Jain A, Mandelia C, Jayaram S. Perception and practice regarding infection control measures amongst healthcare workers in district government hospitals of Mangalore, India. Int J Health Allied Sci. 2012;1:68-73

11. Birhanu D, Amare E, Belay A, Belay Y. Injection Safety Knowledge and Practice among Nurses Working in Jimma University Medical Center; Jimma South West Ethiopia; 2018. J Community Med Public Health Care. 2019;6: 045. 